\title{
Spinal and intravenous midazolan anesthetic effects on fentanyl/ ligdocaine regional anesthesia following back minor orthopedic surgery
}

\author{
Midazolan por via espinal ou endovenosa como coadjuvante da \\ anestesia regional com lidocaína/fentanil em pacientes submetidos a \\ procedimentos cirúrgicos lombares de pequeno porte \\ Midazolan por vía espinal o endovenosa como coadyuvante de la \\ anestesia regional con lidocaína/fentanil en pacientes sometidos a \\ procedimientos quirúrgicos lumbares de pequeño porte
}

\author{
Gabriela Rocha Lauretti ${ }^{1}$ \\ Anita L. Mattos ${ }^{2}$
}

\begin{abstract}
Objectives: the present study was designed to evaluate the usefulness of intravenous and intrathecal midazolan as an adjunct to intrathecal ligdocaine, with or without intrathecal fentanyl. Methods: double-blind study, institutional approval and informed consent; 40 patients scheduled for minor lumbar orthopedic surgery were randomly assigned to one of five groups $(n=8)$. Patients were premedicated with a $4 \mathrm{~mL}$ final intravenous volume (saline or midazolan). Spinal anaesthesia was administered to a $3 \mathrm{~mL}$ final volume $75 \mathrm{mg}$ of lidocaina plus either $33 \mathrm{mg}$ fentanyl or $500 \mathrm{mg}$ midazolan diluted in saline $(0,9 \%)$ - with the patient in sitting position. The latency time for onset of the block (LT), time to progress to T10 sensory level (TT10), duration of the block (Bl), duration of effective analgesia (An), the subjective degree of intraoperative sedation, level of alertness, concentration level and degree of anxiety were specifically
\end{abstract}

\section{RESUMO}

Objetivos: o presente estudo visa avaliar a utilidade da administração do benzodiazepínico midazolan, por via venosa ou espinal, em pacientes submetidos a procedimentos cirúrgicos de pequeno porte sob anestesia regional com lidocaína e fentanil. Métodos: após aprovação do Comitê de Ética em pesquisa e consentimento formal, 40 pacientes foram avaliados de forma duplamente encoberta e prospectiva, sendo divididos aleatoriamente a um dos cinco grupos do estudo $(n=8)$. Os pacientes foram premedicados com midazolan ou solução fisiológica (volume final de $4 \mathrm{~mL}$ ) por via venosa. A anestesia espinal foi administrada com o paciente sentado, utilizando-se $75 \mathrm{mg}$ de lidocaína, $33 \mathrm{mg}$ de fentanil ou $500 \mathrm{mg}$ de midazolan, diluídos em solução fisiológica $(0,9 \%)$, sendo o volume final (3 mL) administrado por via intratecal. Foram avaliados: tempo de latência, tempo de bloqueio motor,

\section{RESUMEN}

Objetivos: el presente estudio visa evaluar la utilidad de la administración del benzodiazepínico midazolan por vía venosa o espinal en pacientes sometidos a procedimientos quirúrgicos de pequeño porte sobre anestesia regional con lidocaina y fentanil. Métodos: después de la aprobación del Comité de Ética en Investigación Formal, 40 pacientes fueron evaluados de forma doble-ciego y prospectivo, siendo divididos de forma aleatoria uno de los cinco grupos del estudio $(n=8)$. Los pacientes fueron pre-medicados con midazolan o solución fisiológica (volumen final $4 \mathrm{~mL}$ ) por vía venosa. La anestesia espinal fue administrada con el paciente sentado, utilizándose $75 \mathrm{mg}$ de lidocaína, $33 \mathrm{mg}$ de fentanil o $500 \mathrm{mg}$ de midazolan diluidos en solución fisiológica (0.9\%), siendo el volumen final administrado por vía intratecal 3 mL. Fueron evaluados:

\footnotetext{
Study carried out at the Department of Biomechanic, Medicine and Reabilitation of the Locomotor Members of Faculdade de Medicina de Ribeirão Preto da Universidade de São Paulo - USP - Ribeirão Preto (SP), Brazil.

'MD, MSc, PhD; Associate Professor of Anesthesiology at Faculdade de Medicina de Ribeirão Preto da Universidade de São Paulo - USP - Ribeirão Preto (SP), Brazil. ${ }^{2} \mathrm{MD}, \mathrm{MSc}$, PhD; Assistant Professor of Anesthesiology at Faculdade de Medicina de Ribeirão Preto da Universidade de São Paulo - USP - Ribeirão Preto (SP), Brazil. 
measured. $\quad \mathrm{P}<0.05$ was considered significant. Results: the addition of midazolan to the intrathecal injection in the absence of fentanyl was the only procedure which caused a statistically significant reduction in LT $(p<0.002)$ and TT10 $(p<0.001)$. Intrathecal midazolan increased the blockade time both with $(\mathrm{p}<0.05)$ and without $(\mathrm{p}<0.02)$ intrathecal fentanyl, but, when given intravenously, this effect failed to reach statistical significance $(p>0,05)$. Both intrathecal fentanyl and midazolan increased the duration of analgesia $(p<0.01)$. With respect to the subjective measures, group 1 served as the control group, demonstrating an alert, fully awake patient who was able to concentrate but showed some anxiety. Conclusions: while all additional treatments resulted in a relaxed patient, only those given intrathecal midazolan remained fully awake, alert and able to concentrate. Intrathecal fentanyl with saline premedication or intravenous midazolan premedication resulted in decreased alertness and inability to concentrate, as well as sleepiness, which was more extreme in the case of those patients given intravenous midazolan.

KEYWORDS: Midazolam/ administration \& dosage; Analgesia; Lidocaine; Fentanyl; Injections, spinal tempo de analgesia, grau de sedação, nível de alerta, nível de concentração e grau de ansiedade. Foi considerado significante $p<0,05$. Resultados: a adição de midazolan por via intratecal na ausência de fentanil foi o único procedimento que resultou em redução do tempo de latência para início do bloqueio $(\mathrm{p}<0,002)$. Midazolan por via intratecal aumentou o tempo de bloqueio motor, com $(p<0,05)$ ou sem $(p<0,02)$ a associação de fentanil intratecal, enquanto que, ao serem administrado por via venosa, não alterou o tempo de bloqueio motor $(\mathrm{p}>0,05)$. Tanto a administração de fentanil ou midazolan intratecais resultaram em aumento do tempo de analgesia $(p<0,01)$. Em relação aos resultados subjetivos, enquanto o grupo 1 atuou como controle, sendo os pacientes alertas, porém com certo grau de ansiedade, os pacientes que receberam midazolan estavam alertas e não ansiosos. Conclusões: os pacientes que receberam midazolan intratecal permaneceram acordados, alertas e com capacidade de concentração, apresentaram menor latência para anestesia e maior tempo de analgesia.

\author{
DESCRITORES: Midazolam/ \\ administração \& dosagem; \\ Analgesia; Lidocaína; \\ Fentanila; Injeções espinhais
}

el tiempo de latencia, el de bloqueo motor, el de analgesia, lo grado de sedación y de ansiedad. El $p<0.05$ fue considerado significativo. $\boldsymbol{R e}$ sultados: la adición de midazolan por vía intratecal en la ausencia de fentanil fue el único procedimiento que resultó en reducción del tiempo de latencia para inicio del bloqueo $(p<0.002)$. Midazolan por vía intratecal aumentó el tiempo de bloqueo motor con $(p<0.05)$ o sin $(p<0.02)$ la asociación de fentanil intratecal, mientras que administrado por vía venosa no cambió el tiempo de bloqueo motor $(p>0.05)$. Tanto la administración de fentanil intratecal o midazolan intratecal resultaron en aumento del tiempo de analgesia $(p<0.01)$. En relación a los resultados subjetivos, el Grupo 1 actuó como Control, siendo los pacientes alertas, pero con cierto grado de ansiedad, mientras los pacientes que recibieron midazolan estuvieron alertas y no ansiosos. Conclusiones: los pacientes que recibieron midazolan intratecal permanecieron alertas y con capacidad de concentración, presentaron menor latencia para anestesia y mayor tiempo de analgesia.

\section{DESCRIPTORES: Midazolan/ administración \& dosificación ; Analgesia; Lidocaína; Fentanilo; Inyecciones espinales}

\section{INTRODUCTION}

Lamina V-type neurons on the spinal dorsal horn, which responded to the bradykinin injection into femoral artery, were studied neurophysiologically in spinal transected cats by the tungsten microelectrode method. It has been demonstrated that the separated and combined antinociceptive effects of fentanyl, clonidine and midazolan, administered intrathecally, can produce reduction in response to noxious stimuli. Fentanyl (25 micrograms), clonidine (30 micrograms) and midazolan $(1 \mathrm{mg})$, separately, suppressed noxious evoked activity at the spinal level. On the other hand, fentanyl (5 micrograms), clonidine (5 micrograms) and midazolan $(0.5 \mathrm{mg})$ produced no significant suppression of the evoked activity. However, the combinations of drugs at lower doses produced supra-additive suppressive effects, which were reversed by each antagonist (naloxone, yohimbine and flumazenil). These findings suggest that, when two of these drugs are combined at sub-analgesic doses, a significant synergistic interaction is exerted. Therefore, the use of these drugs in combination can reduce the total amount of any drug required for analgesia in the spinal cord and also reduce the side effects of these agents ${ }^{1-4}$.

In order to clarify some of these issues, the present study was designed to evaluate the usefulness of intravenous and intrathecal midazolan as an adjunct to intrathecal ligdocaine with or without intrathecal fentanyl. 


\section{METHODS}

After Hospital Ethics Committee approval and written informed patient consent, 40 ASA status I and II patients, scheduled for minor orthopedic lumbar surgery, were randomly assigned to one of five groups $(n=8)$ and the observer was blind to the treatments. All subjects were premedicated in the reception room with a total of $4 \mathrm{~mL}$ administered intravenously (IV). Spinal anesthesia was administered in theatre, with the patient in sitting position, using L3-4 interspace and a 25 gauge needle. The anesthetic volume of the different anesthetic combinations was $3.5 \mathrm{~mL}$, injected at $1 \mathrm{~mL} / 7$ seconds. The patients laid down (supine position) immediately after completion of the spinal injection. The groups were divided as shown in table 1 . A conservative free midazolan solution was available for this study. Standard monitoring techniques were used, including ECG, blood pressure and pulse oximetry.

The latency time for onset of the block (LT) and the time to progress to T10 sensory level (TT10), using a cold device (cotton soaked in alcohol solution), were recorded in seconds. The duration of the block (Bl) was measured as the time to reach Bromage 2 score, and the duration of effective analgesia (An) measured as the time from the intrathecal drug administration to the first need for analgesic administration in recovery room, recorded in minutes.

The subjective degree of intraoperative sedation was recorded as sleepy, slightly sleepy or fully awake. The level of alertness was subjectively analyzed by the patient demeanor, always by the same anesthesiologist. Concentration level was measured by the capacity of promptly and correctly answering direct questions, like "how old are you?"; "how much do you weight?"; "how tall are you?". The correct answers had already been noted in the patient's hospital book. The degree of anxiety was also subjectively measured as anxious or relaxed. All adverse effects were recorded and specific treatments were available. All patients remained in the anesthetic recovery room until apparent complete recovery from anesthesia. Groups 4 and 5 were followed for 40 days as outpatients, in order to assess any possible adverse effect resulting from intrathecal administration of midazolan. Statistical analyses were performed with the ANOVA and the Student's two-tailed t-tests, as required. $\mathrm{P}<0.05$ was considered significant.

\section{RESULTS}

The five groups did not differ statistically in ASA status, male/female ratio, age, weight and height (Table 2). The duration of surgery ranged from 45-60 minutes ( $p>0.05)$. The addition of midazolan to intrathecal injection in the absence of fentanyl was the only procedure which caused a statistically significant reduction in latency of onset and the time to progress to T10, ranging from $80 \pm 12$ seconds, for the control group, to $45 \pm 5$ seconds for patients who received intrathecal midazolan $(p<0.002)$. Intrathecal midazolan increased the blockade time compared to the control group (46 \pm 7 minutes), both with $54 \pm 8$ minutes $(\mathrm{p}<0.05)$ and without fentanyl $(71 \pm 8$ minutes; $\mathrm{p}<0.02)$, but, when given intravenously, this effect failed to reach statistical significance in the present study $(\mathrm{p}>0.05)$. Both intrathecal fentanyl and midazolan, by either route, also significantly increased the duration of analgesia, compared to the control group (ranging from mean of 50 minutes); 70 minutes (spinal fentanyl) to 110 minutes (spinal midazolan) $(\mathrm{p}<0.01)$. With respect to the subjective measures (Table 3 ), group 1 served as the control group, demonstrating an alert, fully awake patient who was able to concentrate, but showed some anxiety. Whi-

\section{TABLE 1 - Groups}

\begin{tabular}{llc}
\hline & Intrathecal drugs $(3.5 \mathrm{ml})$ & Intravenous drugs (4 ml) \\
\hline CG & Ligdocaine $(100 \mathrm{mg})+$ saline & Saline \\
IT-FG & Ligdocaine $(100 \mathrm{mg})+$ fentanyl $(33 \mu \mathrm{g})$ & Saline \\
IT-MG & Ligdocaine $(100 \mathrm{mg})+$ midazolan $(500 \mu \mathrm{g})$ & Saline \\
IV-MG & Ligdocaine $(100 \mathrm{mg})+$ saline & Midazolam $(4 \mathrm{mg})$ \\
IT-M+FG & Ligdocaine $(100 \mathrm{mg})+$ midazolan $(500 \mu \mathrm{g})+$ Fentanyl $(33 \mu \mathrm{g})$ & Saline \\
\hline
\end{tabular}

CG: Control group; IT-FG: Intrathecal fentanyl group; IT-MG: Intrathecal midazolan group; IV-MG: Intravenous midazolan group; IT-M + FG: Intrathecal midazolam + Fentanyl group

TABLE 2 - Demographic data

\begin{tabular}{lcccccc}
\hline & Group 1 & Group 2 & Group 3 & Group 4 & Group 5 & \\
\hline ASA (I/II) & $6 / 2$ & $6 / 2$ & $7 / 1$ & $5 / 3$ & $6 / 1$ & NS* \\
Male/fem. & $6 / 2$ & $5 / 3$ & $5 / 3$ & $6 / 2$ & $5 / 3$ & $\mathrm{NS}$ \\
Age (years) & $34 \pm 9.48$ & $36.75 \pm 14.88$ & $33.5 \pm 3.69$ & $37.6 \pm 8.9$ & $32.25 \pm 13.07$ & $\mathrm{NS}$ \\
Weight (kg) & $71.25 \pm 7.97$ & $68.75 \pm 6.63$ & $64.62 \pm 9.41$ & $72.3 \pm 11.42$ & $65.05 \pm 12.07$ & $\mathrm{NS}$ \\
Height (cm) & $1.71 \pm 0.07$ & $1.66 \pm 0.1$ & $1.63 \pm 0.11$ & $1.72 \pm 0.04$ & $1.65 \pm 0.09$ & $\mathrm{NS}$ \\
\hline
\end{tabular}

Values as mean \pm STD; ${ }^{*} \mathrm{NS}$ : not significant; $\mathrm{p}>0.05$ 
TABLE 3 - Subjetive intraoperative measures

\begin{tabular}{lcccc}
\hline & Sedation & Alertness & Ability to concentrate & Anxiety \\
\hline Group 1 & awake & good & good & anxious \\
Group 2 & slightly sleepy & poor & poor & relaxed \\
Group 3 & sleepy & poor & poor & relaxed \\
Group 4 & awake & good & good & relaxed \\
Group 5 & awake & good & good & relaxed \\
\hline
\end{tabular}

le all additional treatments resulted in a relaxed patient, only those given intrathecal midazolan (groups 4 and 5) remained fully awake, alert and able to concentrate. Intrathecal fentanyl with saline premedication or intravenous midazolan premedication resulted in decreased alertness and inability to concentrate as well as sleepiness, which was more extreme in the case of those patients given intravenous midazolan. No intraoperative adverse effects were noted, except from five patients (two from group 2 , two from group 3, one from group 4) who scratched their nose during the intraoperative period. Groups 4 and 5 were followed as outpatients for 40 days. No adverse effects were noted.

\section{DISCUSSION}

In the present study we have clearly demonstrated that co-administration of fentanyl and midazolan enhances the duration of analgesia associated with a ligdocaine spinal block. The fact that the levels and the time to achieve analgesia were not influenced by fentanyl agrees with the work of others ${ }^{5,6}$ who used bupivacaine as local anaesthetic. The prolongation of spinal local anaesthetics action by fentanyl is also in agreement with others $^{5}$, but this effect seems to be much greater if the local anaesthetic is ligdocaine. It is interesting to note that only intrathecal midazolan, in the absence of fentanyl, significantly reduced the latency and progress of the block. It is possible that groups 2 and 3 patients, who were sleepy and unable to concentrate, were slow to respond to the stimulus, and thus the measured latency and progress times reflected sedation rather than analgesia. However, this explanation cannot be applied to group 4 patients who were alert and able to concentrate. It is known that the lipid solubility, and thus the rate of penetration into the spinal cord, is $\mathrm{pH}$ dependent for both midazolan and ligdocaine. However, the ligdocaine/midazolan solution had a $\mathrm{pH}$ of 6.33 and the addition of fentanyl had little effect $(\mathrm{pH}=6.29)$, which is unlikely to explain the reduced latency observed when fentanyl was not added to ligdocaine/midazolan mixture.

The most prominent finding from the subjective data revealed that intrathecal midazolan maintains its anxiolytic action, without sedating or reducing the ability to concentrate. This is desirable when the communication between the patient and the anesthesiologist, during surgical procedures, is important. Nevertheless, studies involving midazolan must be carefully carried out, once the disposable formulation is not conservative free. In this study, the conservative free midazolan was gently prepared in our pharmacy institution.

It has been suggested that midazolan has a mild analgesic effect due to central suppression of pain perception ${ }^{7}$. Other workers have found that IV midazolan significantly reduces the affective and motivational component of pain, which was experienced by healthy human volunteers subjected to experimental pain ${ }^{8}$. This reduction in the motivational drive was suggested to be due to a central suppression ${ }^{9}$. However, in our study, the preservation of normal alertness, muscle tonus and respiratory rate provide some evidence that the drug is acting spinally, rather than by causing a general depression of the central nervous system. However, these observations are not objective and have qualitative end points ${ }^{10}$.

Studies of combinations in animals provide some information that is prerequisite to successful clinical use. However, such studies can be hampered, because many of the non-opioid drugs have marked effects on motor function, which render difficult responses to interpret in antinociceptive tests ${ }^{10,11}$. Nevertheless, midazolan enhancement in ligdocaine/fentanyl nociception cannot be attributed to the increase in motor deficit in this study. The IV midazolan showed no increase in ligdocaine motor effect, while enhancing its analgesic effect. In addition, although midazolan enhanced both ligdocaine motor and analgesic effects, our patients were alert, quite able to understand what was happening, to communicate and to differentiate a painful sensation even in the presence of motor block. In conclusion, putting all together, these results demonstrate selective actions on BZD and opioid receptor types, with spinal versus cortical distribution. However, a free conservative solution must be available before studies can be done to really certify its real role in anesthesia, as coadjuvant, mainly when an awake - but not anxious - patient is desirable during the procedure. 


\section{REFERENCES}

1. Wang C, Chakrabarti MK, Whitwam JG. Synergism between the antinociceptive effects of intrathecal midazolam and fentanyl on both A delta and $\mathrm{C}$ somatosympathetic reflexes. Neuropharmacology. 1993;32(3):303-5.

2. Ho KM, Ismail H. Use of intrathecal midazolam to improve perioperative analgesia: a meta-analysis. Anaesth Intensive Care. 2008;36(3):365-73.

3. Murali Krishna T, Panda NB, Batra YK, Rajeev S. Combination of low doses of intrathecal ketamine and midazolam with bupivacaine improves postoperative analgesia in orthopaedic surgery. Eur J Anaesthesiol. 2008;25(4):299-306.

4. Boussofara M, Carlès M, RaucoulesAimé M, Sellam MR, Horn JL. Effects of intrathecal midazolam on postoperative analgesia when added to a bupivacaine-clonidine mixture. Reg Anesth Pain Med. 2006;31(6):501-5.
5. Hunt CO, Naulty JS, Bader AM, Hauch MA, Vartikar JV, Datta S, et al. Perioperative analgesia with subarachnoid fentanyl-bupivacaine for cesarean delivery. Anesthesiology. 1989;71(4):535-40.

6. Suzuki N, Beppu S, Uematsu H, Someya T, Kubota Y. Midazolam and somatosensory evoked potentials. Anesth Prog. 1985;32(5):199-201.

7. Coulthard P, Rood JP. An investigation of the effect of midazolam on the pain experience. Br J Oral Maxillofac Surg. 1992;30(4):248-51.

8. Serrao JM, Stubbs SC, Goodchild CS, Gent JP. Intrathecal midazolam and fentanyl in the rat: evidence for different spinal antinociceptive effects. Anesthesiology. 1989;70(5):780-6.

9. Fennessy MR, Sawynok J. The effect of benzodiazepines on the analgesic effect of morphine and sodium salicylate. Arch Int Pharmacodyn Ther. 1973;204(1):77-85.
10.Goodchild CS, Noble J. The effects of intrathecal midazolam on sympathetic nervous system reflexes in man--a pilot study. Br J Clin Pharmacol. 1987;23(3):279- 85.

11. Coulthard P, Rood JP. Objective measurement of the analgesic effect of midazolam in humans. Anesth Prog. 1993;40(2):35-7.

\section{Correspondence}

Gabriela Rocha Lauretti

Rua Maestro Joaquim Rangel, 644

CEP: 14015-110 - Ribeirão Preto (SP), Brazil

Phone: + 55166022211

Fax: + 55166331144

E-mail: grlauret@fmrp.usp.br 